NBER WORKING PAPER SERIES

EMPLOYEE RESPONSE TO

COMPULSORY SHORT-TIME WORK

Victor R. Fuchs

Joyce $P$. Jacobsen

Working Paper No. 2089

\author{
NATIONAL BUREAU OF ECONOMIC RESEARCH \\ 1050 Massachusetts Avenue \\ Cambridge, MA 02138 \\ December 1986
}

This study was supported in part by funds provided by the Alfred $P$. Sloan and Rockefeller Foundations to the National Bureau of Economic Research for the project "Women's Quest for Economic Equality." We are indebted to the "ABC" corporation and its personnel managers for their help in planning and executing the survey, and to the employees of the company for their cooperation. Seymour Martin Lipset provided valuable advice concerning the wording and order of the survey questions, and Claire Gilchrist did an excellent job of producing and processing the survey. We are also grateful to Takeshi Amemiya and Tom MaCurdy for advice concerning the econometric issues, and to Ellen Jones for her helpful research assistance. The research reported here is part of the NBER's research program in Labor Studies. Any opinions expressed are those of the authors and not those of the National Bureau of Economic Research. 
NBER Working Paper \#2089

December 1986

\section{Employee Response to Compulsory Short-Time Work}

\section{ABSTRACT}

This paper reports the results of a survey of over 1500 employees who faced compulsory reductions of 10 percent in hours of work and earnings during the second half of 1985 . The workers were asked how they used the free time and how they viewed the program, and their answers were analyzed in relation to their economic and social characteristics. On average, the workers spent 12 percent of the free time in uncompensated work for the company, 43 percent in other work (mostly housework, childcare, and other nonmarket chores), and 45 percent in leisure-time activities such as resting, reading, and hobbies. Ceteris paribus, education and income were positively related to percentage of time spent in company work, and age was negatively related. Time spent in other work rose with the presence of children, especially for women. Employee reaction to the program was generally favorable; married women were most positive and married men least positive. Workers 45 years of age and over were significantly more positive than those 35-44. There was a strong connection between time use and reaction to the program; workers who spent more of their free time working without pay at the company or in home production were much less positive than those who spent more time in leisure activities.

Victor R. Fuchs NBER 204 Junipero Serra Boulevard Stanford, CA 94305
Joyce Jacobsen NBER 204 Junipero Serra Boulevard Stanford, CA 94305 
EMPLOYEE RESPONSE TO COMPULSORY SHORT-TIME WORK

by

Victor R. Fuchs and Joyce P. Jacobsen

\section{Introduction}

When a firm experiences a decline in demand, it can respond in a variety of ways. If the decline is expected to be temporary, one frequently pursued strategy is to maintain price and cut back on output and inputs, especially labor. This reduction usually takes the form of layoffs for a portion of the workforce, but sometimes the firm shortens the hours of work for all or virtually all of the employees. Such shorttime compensation (STC), or work-sharing, is alleged to have numerous advantages as compared with conventional layoffs (Best and Mattesich 1980, Best 1985), but very little is known about employee response to STC.

The initiation by a major manufacturing company (called $A B C$ in this paper) of a six-month, company-wide program of STC in the second half of 1985 provided an excellent opportunity to gather systematic data concerning employee response to short-time work. How do employees spend the additional time off? Do they work more hours at nonmarket production, or do they enjoy true leisure? Do some employees come in to work anyway, even though they are not paid? What do workers think of STC after having direct experience with it? How does it affect them personal1y? Does employee use of time and their reaction to the program vary systematically with sex, marital status, or other characteristics? 
This paper reports the results of a survey of a sample of over 1,500 $A B C$ employees taken a few months after the STC program ended. First we present a brief review of the literature on STC, followed by a description of the $A B C$ company and the survey. The employees' use of the time off and their reactions to the program are subjects of the multivariate analysis reported in sections 4 and 5. The paper concludes with a discussion of the implications of the findings for policy and future research.

\section{Review of Literature}

Much of the literature on STC (used synonymously with worksharing) is exhortatory rather than descriptive or analytical. Numerous social benefits are claimed for STC, including less disruption associated with unemployment (e.g., crime, poor health) and less need for redistributive programs such as public assistance or public service jobs. The Federal Republic of Germany makes more extensive use of worksharing than does any other country, partly because the unemployment rate is seen as a "foreign policy issue"--"an immediate and meaningful reflection of the 'score' of the continuing East-West political and economic competition" [Meisel 1984].

In the United States there were extensive efforts to promote worksharing by both Presidents Hoover and Roosevelt during the Great Depression but the practice fell into disuse until the mid-1970s [Nemirow 1984]. By 1986 there were 11 states that provided unemployment insurance benefits for workers who face compulsory short workweeks, but only two states, California and Arizona, had more than 10,000 workers drawing such benefits in 1985. Even in California, the state that has led the way for STC, less than one percent of total unemployment benefits are paid to workers who are on short time [Business Week 1986]. 
Employers are said to like STC because it improves employee morale, lowers administrative costs, eliminates future costs of hiring and training new workers, and provides greater flexibility [MaCoy and Morand 1984]. A survey of 292 California firms who used STC reported 50 percent as highly or extremely satisfied and only 2 percent as highly or extremely dissatisfied. Comparable figures for a Canadian survey involving 296 respondents were 38 and 4 percent, respectively [Reid and Meltz 1984].

Less is known about employee response to STC. Workers are said to benefit from continued job attachment and continued fringe benefit protection. A 1980 survey of workers elicited 953 answers to a hypothetical question concerning preferences for STC as an alternative to layoffs. $1 /$ A substantial majority ( 64 percent) said they would favor STC; 19 percent said they would prefer a layoff program; and the balance were neutral [Best 1981]. Women were more likely than men to indicate a preference for STC (69 vs. 61 percent), but the difference was not statistically significant. In general there was very little systematic relation between socioeconomic characteristics and attitudes toward STC.

A Canadian study attempted to infer employee attitudes toward worksharing by looking at the incidence of such provisions in collective bargaining agreements in Ontario in August 1978 [Me1tz, Reed and Swartz 1981]. Out of 2,163 agreements covering 816,000 employees, 6.2 percent of the agreements covering 7.6 percent of the employees provided for worksharing. The investigators ran regressions across industries with the share of the employees covered by a worksharing provision as the dependent variable. $2 /$ The independent variables were average weekly earnings, percentage of employees female, percentage of employees part-time, and percentage of employees ages 25-54. The coefficient for percent female was 
consistently significantly different from zero and indicates that for every increase of one percentage point in that variable there was an increase of almost one percentage point in the incidence of worksharing. The wage and age variables were not significantly different from zero; the coefficient for the percent part-time has a significant negative coefficient.

The California Employment Development Department surveyed (by telephone) approximately 450 workers who experienced STC during 1978-80 [State of California 1982]. In response to a question about time use, 60 percent of the respondents mentioned "work around the house," and the second most frequently mentioned use (23 percent) was "time with family." A11 other possible uses (e.g., "traveled," "looked for a new job," "read or studied") were mentioned by 71 percent of the respondents. The total exceeds 100 percent because many workers mentioned more than one use; the amount of time spent in each one was not asked. About 40 percent of the respondents said they put a "high value" on the additional free time; 33 percent said "moderate value," and 27 percent "little or no value." A great majority favored repeated use of the program (as an alternative to layoffs) and only five percent were opposed to future use.

There is, apparently, no study of employee response to an actual STC program that relates time use and opinion to socioeconomic characteristics in a multivariate framework or that explores whether workers' use of time affects their opinion of the program. The survey and analysis presented in this paper help to fill that gap. 


\section{Description of Survey}

This section provides some background on $A B C$ and its implementation of the short-time program. This is followed by a description of how the survey was formulated and carried out. Finally, there is a discussion of the representativeness of the responses relative to the sample population.

$A B C$ is a large manufacturing firm with multiple product 1 ines and worldwide sales and production. It has a reputation for maintaining good employee relations; it offers a competitive and varied benefit package, and has, since its inception, been committed to a no-layoff philosophy. The standard workweek is normally 40 hours, but the company allows flextime for al1 employees. $A B C$ is less accommodating with respect to working fewer than 40 hours per week, but there are some permanent part-time employees and a few shared positions. Al1 in a11, less than 5 percent of the employees normally work fewer than 40 hours per week.

In 1985, $A B C$ began to experience a slowdown in business. As layoffs were ruled out and worksharing was a strategy that had worked for the firm twice before in the 1970 s, it was a natural policy choice now that the firm needed to cut costs. In July 1985 management decided to try a Friday off without pay. This experiment was deemed a success, and in August the program was put into full swing. All employees were subject to a program of working 90 percent of their previous formal hours for 90 percent of their previous monthly pay. 3 / In California, the employees who had to take days off were eligible for compensation from the state unemployment insurance fund. Compensation was based on salary level up to a maximum of $\$ 32$ per day off for workers earning more than $\$ 5,533$ in their highest quarter. Information on the California worksharing program was made available by the firm (stacks of applications and samples of completed 
forms were prominently displayed at the workplace), and $A B C$ personnel managers estimate that over 75 percent of the workforce received insurance benefits.

The program was presented as a short-term measure, scheduled to end by January 1986. On January 1 it was replaced by a program of a 5 percent reduction in both pay and hours. In March a new policy was announced, effective April 1, which allowed each division to set its own rules regarding STC. Some divisions returned to full-time (including two of the three divisions covered in this study), some did not, and some had different policies for different workers. This continuation of a shorttime schedule beyond the period originally expected may have led to different answers about employee reactions than would have occurred otherwise, even though the survey asked specifically about the earlier, uniform policy.

In November 1985 we approached $A B C$ with a proposal for a survey and were told to delay the request until after the program was scheduled to end. In January we again expressed our interest in surveying part of their workforce, preferably only workers in one general area, so as to control for factors which might vary geographically. In late March, $A B C$ granted access to three California divisions whose heads had agreed to cooperate in distributing the survey. A short questionnaire was developed, tested on two focus groups of workers at a division which was not included in the survey sample, and then distributed along with the regular paycheck distribution to all workers in the three divisions in early April, 1986. Anonymity and confidentiality was stressed and postpaid envelopes were included so that the questionnaires could be mailed directly to us. The questionnaire was short--and age, education, and income questions were 
phrased in ranges, so as to elicit a high response rate. The appendix contains a facsimile of the questionnaire.

Out of an estimated sample population of $3,553,1,911$ questionnaires were returned, yielding a response rate of 53.8 percent. Of these 1,911 questionnaires, 123 (6.4 percent) were not used due to incomplete or unclear information about time use and/or opinion of the program.4/ Another 265 questionnaires (13.9 percent) were not used due to missing information on one or more independent variables. However, those questionnaires missing only occupation were kept, and this fact noted. Thus the detailed analysis is based on 1,523 observations, 42.9 percent of the sample population. $5 /$

How representative are these observations of the underlying distribution of workers? Table 1 shows a simple comparison--the breakdown of the sample population by sex, age, race, pay, and job type, provided by the firm. These one-way frequencies are compared to those of the 1,523 usable responses. Women and whites, younger workers, and workers in the middle and lowest salary ranges are slightly over-represented.

\section{Results: Use of Time}

Five categories were originally specified that people might divide their time among in percentage terms. The percent of time spent in the categories of volunteering, paid work, and other (usually schoolwork or illness) was quite smal1. 6 / It was decided that these miscellaneous responses were best incorporated into a three-category system, for analytical and explicative ease. These categories are: 1) ABC Work--time spent working either at the firm or on company projects at home;

2) Leisure-time spent resting, traveling, socializing, or doing hobbies 
Table 1. Comparison of the distribution of usable responses to that of the sample population.

\section{Percent of \\ fu11 population \\ $(\mathrm{N}=3,553)$}

Percent of

usable responses

$(\mathrm{N}=1,523)$

Sex
Women
45.6
52.1
Men
54.4
47.9

Own Income $(\$ 1,000 s)$

$\begin{array}{rrr}<15 & 2.5 & 4.0 \\ 15-25 & 36.1 & 27.8 \\ 25-35 & 29.2 & 33.9 \\ 35-45 & 18.4 & 21.3 \\ 45-60 & 10.4 & 11.2 \\ >60 & 3.4 & 1.7\end{array}$

Job Type*

Management

Other exempt

Nonexempt
17.7

36.7

45.6
21.3

38.7

39.9

Age

$$
\begin{array}{r}
<25 \\
25-34 \\
35-44 \\
45-54 \\
55-64 \\
\geq 65
\end{array}
$$

9.0

42.9

25.2

14.7

7.7

0.5
9.5

47.3

23.2

14.2

5.4

0.5

Race

White (non-Hispanic) other
68.8

31.2
76.0

24.0

*Usable responses number 1,402 ; sample population figures are out of 3,865 individuals, as data were not available for the same period. 
or sports; 3) Other Work--time spent mostly on nonmarket production, including housework, childcare, running errands, and volunteer work, but also including other market work and investment (schoolwork, looking for another job). $7 /$

Originally the study was partially geared towards studying changes in how time was used over the course of the program. Therefore, the workers were asked to try to recall how they allocated their time both in the first month of the program (August 1985) and in the last month that all divisions were subject to the program (December 1985). For most workers, there were negligible changes in how time was allocated between the two months. Therefore, the average of the two months is used in the following analysis. Use of the simple mean rather than using the time allocation of one or the other month also has the feature of averaging the two types of time-off which the workers experienced: in August, September and October the days off were scheduled for alternate Fridays so the workers had three-day weekends; in November and December the days off were bunched together with scheduled holidays and vacation days so that the workers had an extended holiday period.

Table 2 shows the mean values for percent of time spent in the three categories for the set of usable responses, stratified by personal characteristics. The overal1 means are: 45.3 percent of time devoted to Leisure, 11.8 percent to $\mathrm{ABC}$ Work, and 42.9 percent spent on other Work. Married persons spend less time in Leisure and more time in Other Work than unmarried people do. When both sex and marital status are taken into account, a pattern emerges that married women spend the most time in other Work, followed by married men, unmarried women, and unmarried men. Employees with children spend much more time in Other Work than people without children, cutting down on both $A B C$ Work and Leisure. $A B C$ Work 
Table 2. Employee time use on days off by socioeconomic characteristics.

$\overline{\mathrm{Al1}}$

11.8

By sex

Women

Men

By marital status

Married

Not married

By sex \& marital status

Married women

Married men

Not-married women

Not-married men

By children

No child

Child $<6$

Child, not $<6$

12.4

8. 3

11.9

By education

Not beyond high school

Some college

College graduate

Some graduate work

Graduate degree

8.8

15.0

11.6

12.0

40.3

51.0

48.1

37.0

816

707

8. 3

40.8

47.8

54.8

49.6

35.4

36.6

41.7

44.6

49.3

46.2

41.6

25.0

By own income $(\$ 1,000 s)$

$<15$

$15-25$

$25-35$

$35-45$

$>45$

By job type

Management

Other exempt

Nonexempt

Job type missing

By age

$$
\begin{array}{r}
<35 \\
35-44 \\
\geq 45
\end{array}
$$

6.2

2. 8

10.4

18.0

26.0

25.4

12.8

3.7

10.4

13.5

12.2

6.4

12.6

9.3

other

By inclusion

Usable sample

Dropped observations
11.8

13.9
50.9

45.2

42.8

30.2

38.0

56.3

51.5
34.9

44.3

49.6

44.2

41.0

41.3

48.4

44.3

45.8

47.1

41.3

44.7

46.3

41.8

41.1

48.9

1,157

366

58.9

424

517

325

196

33.0

33.3

299

543

560

121

52.0

43.8

864

46.5

354

305

48.9
417

399

377

330

1,033

205

285

54.9

193

489

452

129

$33.4 \quad 260$

61

45.3

42.9

1,523

40.4

45.7 
rises sharply with education, while Other Work drops to offset it. A similar pattern is found as salary level rises. In the occupation groups managers do more ABC Work; other exempt workers (nonmanagerial persons who are on salaries with no overtime pay) are slightly over the mean on $A B C$ Work, but spend more time than the managers in both Leisure and Other Work. Nonexempt workers (those who can collect overtime pay) spend significantly less time in $A B C$ Work and a much higher amount of time in Other Work. Younger people spend less time in Other Work, but more time on $A B C$ Work than older people. Finally, with regard to race, non-Hispanic whites spend more time in both Leisure and ABC Work than all other groups. The last two lines of Table 2 compare the mean time use and opinions of persons in the usable sample to the responses of those persons who were deleted due to their not providing full information about their personal characteristics. The deleted respondents spent less time in leisure activities and more time in both market and nonmarket work. These differences, however, are not large.

An examination of the means, however, does not do full justice to the data. A smoothed distribution of all respondents for each of the three categories of time use is shown in Figure 1. While responses are distributed fairly normally for Leisure and Other Work, there is evidence of bunching at the endpoints, and 68 percent of the respondents did no $A B C$ Work. This bunching means that modeling time use using a conventional set of demand equations and estimating this system using ordinary least squares will lead to inconsistent parameter estimates [Wales and Woodland 1983]. In an attempt to remedy these problems, a model of sequential decisionmaking, involving correction for the upper and lower bunching of the data and a partial satisfaction of the adding-up constraint, has been used. 

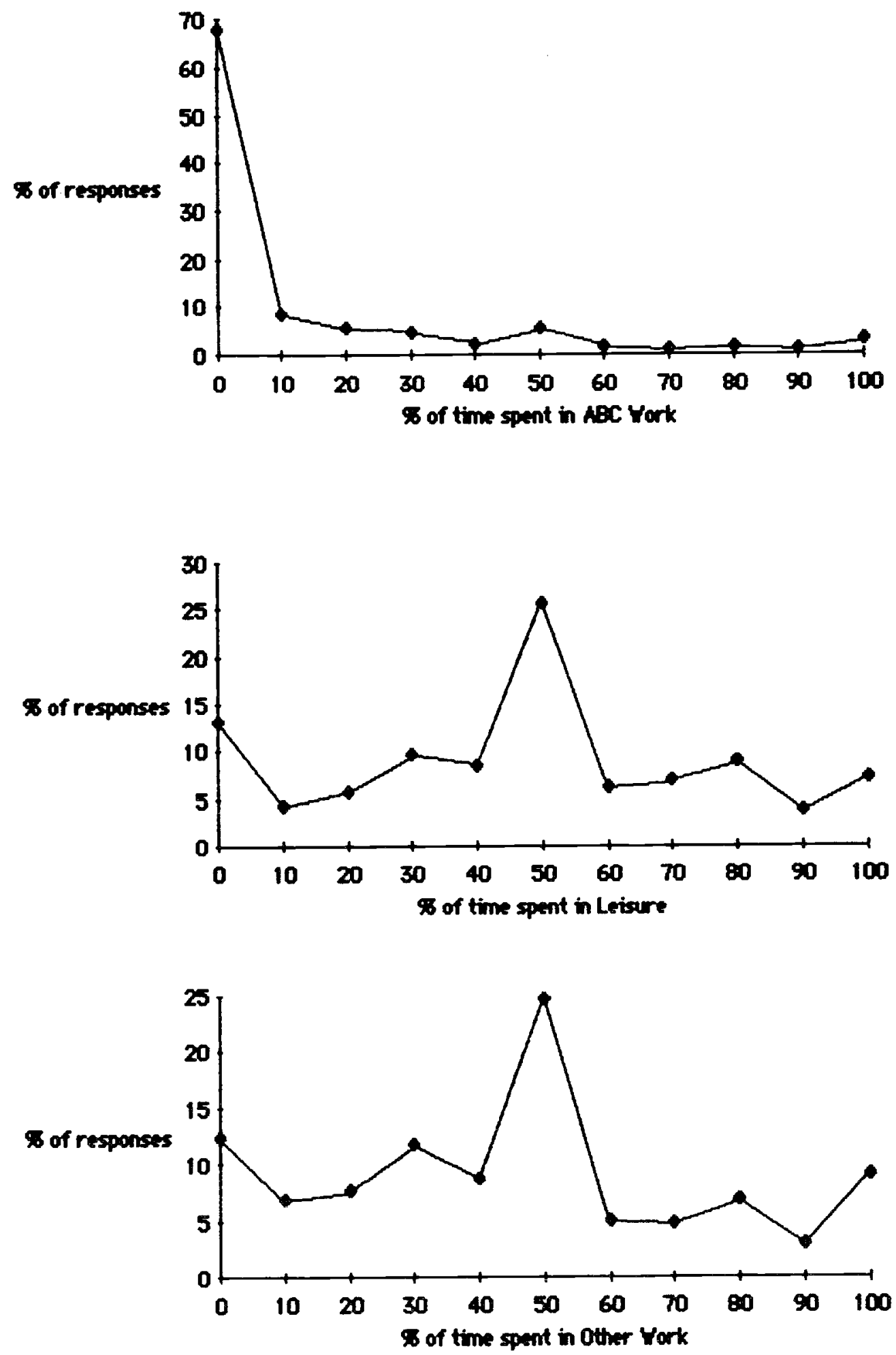

Figure 1. Distribution of responses by percent of time spent in various activities. 
In this model, the person faced with how to spend his time makes two sequential decisions. First, the worker makes the decision about whether or not he will do $A B C$ Work and how much time to spend doing it. This decision is assumed to come first because for a large number of respondents, there was no choice in this matter. Most hourly employees needed a special pass in order to enter the plant on the days off and their work was not of a type which could be undertaken off the premises: these employees only had to decide how to divide their time between Leisure and Other Work. On the other end of the spectrum, some salaried workers, especially managers, felt compelled to do ABC Work; certainly some of the written comments on the survey forms indicated that they felt this was not a choice for them. 8 / After the decision as to how much time to spend doing $A B C$ Work has been made, the worker allocates the remaining time between Leisure and Other Work. $9 /$ Finally, his opinion of the program is hypothesized to depend, in part, on how he allocates his time. Opinion is not hypothesized to affect time use.

Operationally, this model of time use and opinion consists of four equations. First, the percentage of time devoted to $A B C$ Work as a function of independent variables is estimated using a two-limit tobit specification where the truncation points are 0 and 100 percent of time. Then, two equations with percent of time spent on Leisure and Other Work as the dependent variables are estimated using the same independent variables, again using a double-truncated tobit, where the bottom limit is again 0 , but here the upper 1 imit varies for each worker: it is set to 100 percent minus the amount of $A B C$ Work performed. $10 /$ Final1y, as discussed in section 5 of this paper, an equation is run with opinion as the dependent variable, using the technique of ordered probit, and using the same independent variables as listed below plus the percentages of time spent 
in $A B C$ Work and Leisure.

Formally, estimation of the time use part of the model involves maximizing functions (A) and (B) below.

The basic tobit model postulates the existence of a latent variable

$$
Y_{i}^{*}=\beta^{\prime} X_{i}+u_{i}
$$

where $Y_{i}^{*}$ is the latent variable for person $i, i=1, \ldots, n$

$x_{i}$ is a set of explanatory variables for $i$, and

$u_{i}$ is the residual for $i$.

However, $Y_{i}$ is observed rather than $Y_{i}^{*}$, where:

$$
Y_{i}=\left\{\begin{array}{l}
L_{1 i} \text { if } Y_{i}^{*} \leq L_{1 i} \\
Y_{i}^{*} \text { if } L_{1 i}<Y_{i}^{*}<L_{2 i} \\
L_{2 i} \text { if } Y_{i}^{*} \geq L_{2 i}
\end{array}\right.
$$

and the likelihood function is given by:

$$
\begin{gathered}
L\left(\beta, \sigma \mid Y, X, L_{1}, L_{2}\right)= \\
\prod_{Y_{i}=L_{1 i}} \Phi\left(\frac{L_{1 i}-\beta X_{i}}{\sigma}\right) \prod_{Y_{i}=Y_{i}^{*}}\left[\frac{1}{\sigma} \phi\left(\frac{Y_{i}-\beta^{\prime} X_{i}}{\sigma}\right)\right] \prod_{Y_{i}=L_{2 i}}\left[1-\Phi\left(\frac{L_{2 i}-\beta^{\prime} X_{i}}{\sigma}\right)\right]
\end{gathered}
$$

In the case of $Y_{i}^{*}=W_{i}^{*}=$ the desired amount of $A B C$ Work and $Y_{i}=W_{i}=$ the observed amount of $A B C$ Work,

$$
\left\{\begin{array}{l}
L_{1 i}=0 \\
L_{2 i}=100
\end{array}\right\} \text { for all } i
$$


and

(A) $\quad L(\beta, \sigma \mid w, x)=$

$$
\prod_{W_{i}=0} \Phi\left(\frac{-\beta x_{i}}{\sigma}\right) \prod_{w_{i}=w_{i}}\left[\frac{1}{\sigma} \phi\left(\frac{w_{i}-\beta x_{i}}{\sigma}\right)\right] \prod_{W_{i}=100}\left[1-\Phi\left(\frac{100-\beta x_{i}}{\sigma}\right)\right]
$$

While for desired Leisure, $\mathrm{LE}_{\mathbf{i}}^{*}$,

$$
\left\{\begin{array}{l}
L_{1 i}=0 \\
L_{2 i}=\left(100-w_{i}\right)
\end{array}\right\} \text { for all } i
$$

And

(B) $\quad \mathrm{L}\left(\beta, \sigma \mid \mathrm{LE}, \mathrm{X}, \mathrm{L}_{2}\right)=$

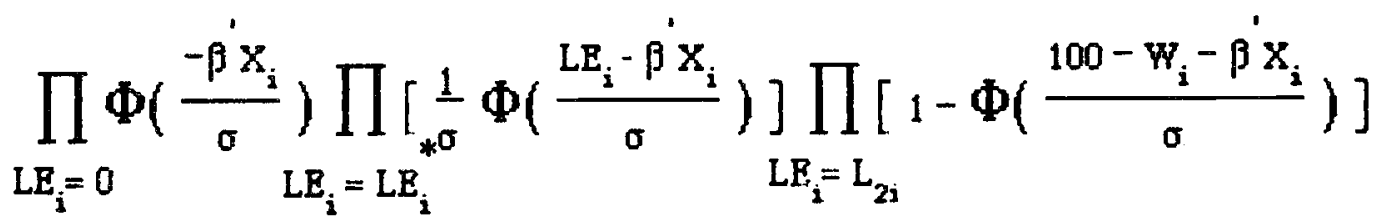

Function (B) can then be reestimated substituting in observed and desired Other Work for Leisure to yield a set of parameters relating the independent variables to Other Work. By assumption, $\mathrm{ABC}$ Work does not enter (B) as an explanatory variable.

The parameters of the likelihood functions were estimated using the ML procedure in TSP 4.1. Standard errors were calculated using Newtonian analytic second derivatives. 
The matrix of independent variables includes education (EDUC); dummy variables to indicate the presence of at least one child under the age of six in the worker's household (YNGKID) and the presence of no young child, but at least one child over five years of age (OLDKID); race (NONWHITE); own salary (OWNINC); and spouse's salary (SPOUSINC). Three job dummies are included, indicating, in order, managers (MGT), other exempt workers (OTHEX), and nonexempt workers (NONEX). The omitted class are those observations where occupation is coded as missing. Two age dummies are also included, to signify those under $35(<35)$ and those 45 and over $(\geq 45)$. In order to expose structural differences, the tobit equations are estimated separately for married and unmarried individuals, in which case a dummy variable to indicate sex is included (WOMAN); and also separately by sex, in which case a marital status dummy is included (MARRIED). As noted in section 3, education, and salary variables are measured with error, as they are set at the midpoints of the indicated ranges and subject to upper and lower truncation.

There are two problems with using this model to predict how a person will allocate time among the three uses. First, since within-equation variance is not fully accounted for by the included variables, each use of time is predicted with error. Second, the model is not constrained to make the three predicted uses of time sum to 100 for each person. An al ternative method which satisfies the adding-up constraint, but which yields higher prediction error for each time component, is to estimate only two of the three equations ( $A B C$ Work, by hypothesis, is estimated first, and then either Leisure or other Work). The predicted values are calculated from these two equations, checked to make sure each is between 0 and 100 (higher and lower values are set at these values), and then 
subtracted from 100 to yield an estimate for the percent of time spent in the third area. This estimate is also constrained to be between 0 and 100 . To compare the results of these two methods, the mean absolute error for each time use component under each method was calculated. In general, the differences were not large. For example, for married persons, using direct estimation of function (B) for Other Work yields a prediction error of 22.3 percent. Calculating Other Work as the corrected residual time use has an error of 23.8 percent. For the model as a whole, for married persons, the three separately-calculated estimates of the time use components sum to 9 percent more or less, on average, than 100 percent. Prediction is slightly better for women and not-married persons and slightly worse for men. Since the problem of not meeting the overall constraint appears to be small relative to regular prediction error, all twelve estimated equations are reported.

Table 3 shows the results of these estimations. For married individuals, EDUC, OWNINC, and $<35$ have a positive effect on percent of time spent doing $A B C$ Work, while the dummy variables YNGKID and NONWHITE exert negative influences. The percent of time spent in Leisure for marrieds is negatively related to YNGKID and OLDKID and positively related to SPOUSINC; the opposite pattern appears for Other Work. Not-married individuals also increase time spent in $A B C$ Work with EDUC, OWNINC, and < 35, and spend less time if they are in the group with dummy NONEX. They increase the percent of time devoted to Leisure only if $<35$, and decrease it in response to the presence of YNGKID, OLDKID, or WOMAN. Again, Other Work exhibits the opposite pattern to that of Leisure.

Many variables are significant in the equations for women: EDUC, OWNINC, and < 35 are again positively related to $A B C$ Work, and YNGKID is significantly negative. In the Leisure equation, only SPOUSINC is 
Table 3. Results of tobit estimations, percent of time spent in $A B C$ Work, Leisure, and Other Work (standard errors in parentheses).

\begin{tabular}{|c|c|c|c|c|c|c|}
\hline & \multicolumn{3}{|c|}{$\begin{array}{r}\text { Married } \\
(\mathrm{N}-816)\end{array}$} & \multicolumn{3}{|c|}{$\begin{array}{c}\text { Not married } \\
(\mathrm{N}-707)\end{array}$} \\
\hline & $\overline{\mathrm{AB}} \overline{\mathrm{C} \text { Work }}$ & Leisure & Other Work & $\overline{\mathrm{ABC} \text { Work }}$ & Leisure & Other Work \\
\hline WOMAN & $\begin{array}{l}-2.60 \\
(6.66)\end{array}$ & $\begin{array}{l}-3.68 \\
(3.31)\end{array}$ & $\begin{array}{c}4.94 \\
(3.26)\end{array}$ & $\begin{array}{l}-0.20 \\
(4.69)\end{array}$ & $\begin{array}{l}-6.88 \star \\
(2.75)\end{array}$ & $\begin{array}{l}7.27 x * x \\
(2.62)\end{array}$ \\
\hline MARRIED & - & 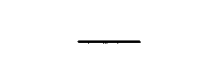 & - & - & - & - \\
\hline YNGKID & $\begin{array}{r}-17.57 * \\
(7.01)\end{array}$ & $\begin{array}{c}-10.47 \star \star \\
(3.39)\end{array}$ & $\begin{array}{l}15.28 * \star \\
(3.35)\end{array}$ & $\begin{array}{c}-8.38 \\
(14.75)\end{array}$ & $\begin{array}{c}-17.22 \star * \\
(6.66)\end{array}$ & $\begin{array}{l}15.60 x \\
(6.38)\end{array}$ \\
\hline OLDKID & $\begin{array}{c}3.32 \\
(6.80)\end{array}$ & $\begin{array}{c}-10.44 \star \star \\
(3.28)\end{array}$ & $\begin{array}{l}8.68 * \star \\
(3.24)\end{array}$ & $\begin{array}{c}3.17 \\
(8.07)\end{array}$ & $\begin{array}{c}-18.95 * * \\
(4.30)\end{array}$ & $\begin{array}{l}18.00 * x \\
(4.12)\end{array}$ \\
\hline SPOUS INC & $\begin{array}{l}-0.16 \\
(0.20)\end{array}$ & $\begin{array}{c}0.24 \star \\
(0.10)\end{array}$ & $\begin{array}{l}-0.24 * \\
(0.10)\end{array}$ & $\ldots$ & $\longrightarrow$ & - \\
\hline EDUC & $\begin{array}{l}6.83 * * \\
(1.50)\end{array}$ & $\begin{array}{l}-1.00 \\
(0.73)\end{array}$ & $\begin{array}{l}-0.80 \\
(0.73)\end{array}$ & $\begin{array}{l}3.26 * \\
(1.38)\end{array}$ & $\begin{array}{c}0.35 \\
(0.80)\end{array}$ & $\begin{array}{l}-1.07 \\
(0.76)\end{array}$ \\
\hline OWNINC & $\begin{array}{l}1.44 * * \\
(0.31)\end{array}$ & $\begin{array}{c}0.02 \\
(0.15)\end{array}$ & $\begin{array}{l}-0.46 * \star \\
(0.15)\end{array}$ & $\begin{array}{l}0.85 * \star \\
(0.30)\end{array}$ & $\begin{array}{c}0.08 \\
(0.18)\end{array}$ & $\begin{array}{l}-0.32 \\
(0.17)\end{array}$ \\
\hline MGT & $\begin{array}{c}1.50 \\
(10.72)\end{array}$ & $\begin{array}{c}0.77 \\
(5.40)\end{array}$ & $\begin{array}{l}-3.86 \\
(5.34)\end{array}$ & $\begin{array}{l}13.74 \\
(9.56)\end{array}$ & $\begin{array}{l}-6.26 \\
(5.89)\end{array}$ & $\begin{array}{l}-2.49 \\
(5.62)\end{array}$ \\
\hline OTHEX & $\begin{array}{l}-19.04 \\
(10.32)\end{array}$ & $\begin{array}{c}3.33 \\
(5.06)\end{array}$ & $\begin{array}{c}4.31 \\
(5.00)\end{array}$ & $\begin{array}{l}-4.97 \\
(8.73)\end{array}$ & $\begin{array}{l}-1.83 \\
(5.19)\end{array}$ & $\begin{array}{c}3.54 \\
(4.95)\end{array}$ \\
\hline NONEX & $\begin{array}{l}-18.70 \\
(10.61)\end{array}$ & $\begin{array}{l}-2.21 \\
(4.86)\end{array}$ & $\begin{array}{c}6.03 \\
(4.80)\end{array}$ & $\begin{array}{c}-28.00 * * \\
(9.70)\end{array}$ & $\begin{array}{c}1.61 \\
(5.23)\end{array}$ & $\begin{array}{c}4.68 \\
(4.99)\end{array}$ \\
\hline$<35$ & $\begin{array}{l}15.67 * \\
(6.97)\end{array}$ & $\begin{array}{l}-3.34 \\
(3.39)\end{array}$ & $\begin{array}{l}-0.62 \\
(3.36)\end{array}$ & $\begin{array}{l}19.29 \star \star \\
(6.90)\end{array}$ & $\begin{array}{r}8.45 \star \\
(3.68)\end{array}$ & $\begin{array}{c}-11.50 \times * x \\
(3.52)\end{array}$ \\
\hline$\geq 45$ & $\begin{array}{r}-12.42 \\
(7.73)\end{array}$ & $\begin{array}{l}-0.77 \\
(3.62)\end{array}$ & $\begin{array}{c}3.52 \\
(3.58)\end{array}$ & $\begin{array}{l}-8.81 \\
(9.04)\end{array}$ & $\begin{array}{c}3.89 \\
(4.55)\end{array}$ & $\begin{array}{l}-0.34 \\
(4.35)\end{array}$ \\
\hline NONWHITE & $\begin{array}{r}-13.35 * \\
(6.45)\end{array}$ & $\begin{array}{l}-0.69 \\
(2.98)\end{array}$ & $\begin{array}{c}4.07 \\
(2.95)\end{array}$ & $\begin{array}{c}3.18 \\
(5.55)\end{array}$ & $\begin{array}{l}-5.60 \\
(3.14)\end{array}$ & $\begin{array}{c}2.69 \\
(3.00)\end{array}$ \\
\hline CONSTANT & $\begin{array}{c}-166.40 * * \\
(24.41)\end{array}$ & $\begin{array}{l}55.16 * * \\
(11.09)\end{array}$ & $\begin{array}{l}71.14 \star \star \\
(10.94)\end{array}$ & $\begin{array}{c}-102.29 * \star \\
(23.33)\end{array}$ & $\begin{array}{l}47.12 * \star \\
(12.66)\end{array}$ & $\begin{array}{l}60.24 \times x \\
(12.09)\end{array}$ \\
\hline $\begin{array}{l}\text { Log of } \\
\text { likelihood }\end{array}$ & -1462 & -3289 & -3280 & -1451 & -2880 & -2862 \\
\hline
\end{tabular}


Table 3 (Concluded)

Men
$(\mathrm{N}=729)$

$\overline{A B C \text { Work Leisure Other Work }}$
Women

$(\mathrm{N}=794)$

\begin{tabular}{|c|c|c|c|c|c|c|}
\hline WOMAN & & & & & & \\
\hline MARRIED & $\begin{array}{l}-2.85 \\
(8.30)\end{array}$ & $\begin{array}{c}-19.81 * * \\
(4.91)\end{array}$ & $\begin{array}{l}20.78 * * \\
(4.80)\end{array}$ & $\begin{array}{c}8.96 \\
(10.90)\end{array}$ & $\begin{array}{r}-12.55 * \\
(5.01)\end{array}$ & $\begin{array}{l}13.48 * * \\
(4.93)\end{array}$ \\
\hline YNGKID & $\begin{array}{r}-14.17 \\
(7.90)\end{array}$ & $\begin{array}{l}-6.60 \\
(4.43)\end{array}$ & $\begin{array}{l}12.11 \star \star \\
(4.35)\end{array}$ & $\begin{array}{r}-19.91 * \\
(8.92)\end{array}$ & $\begin{array}{c}-18.02 * * \\
(3.84)\end{array}$ & $\begin{array}{l}20.89 * * \\
(3.76)\end{array}$ \\
\hline OLDKID & $\begin{array}{c}4.88 \\
(7.55)\end{array}$ & $\begin{array}{c}-6.04 \\
(4.33)\end{array}$ & $\begin{array}{r}3.07 \\
(4.23)\end{array}$ & $\begin{array}{r}2.60 \\
(7.04)\end{array}$ & $\begin{array}{l}-16.12 \star \star \\
(3.19)\end{array}$ & $\begin{array}{l}16.08 * x \\
(3.15)\end{array}$ \\
\hline SPOUSINC & $\begin{array}{c}0.22 \\
(0.26)\end{array}$ & $\begin{array}{r}0.18 \\
(0.16)\end{array}$ & $\begin{array}{c}-0.30 \\
(0.16)\end{array}$ & $\begin{array}{r}-0.31 \\
(0.26)\end{array}$ & $\begin{array}{c}0.25 * \\
(0.12)\end{array}$ & $\begin{array}{c}-0.25 * \\
(0.12)\end{array}$ \\
\hline EDUC & $\begin{array}{l}5.23 * * \\
(1.43)\end{array}$ & $\begin{array}{l}-1.26 \\
(0.85)\end{array}$ & $\begin{array}{l}-0.50 \\
(0.83)\end{array}$ & $\begin{array}{l}5.05 * * \\
(1.44)\end{array}$ & $\begin{array}{c}0.21 \\
(0.68)\end{array}$ & $\begin{array}{l}-1.25 \\
(0.66)\end{array}$ \\
\hline OWNINC & $\begin{array}{l}1.04 \star \star \\
(0.28)\end{array}$ & $\begin{array}{l}-0.02 \\
(0.17)\end{array}$ & $\begin{array}{l}-0.39 * \\
(0.16)\end{array}$ & $\begin{array}{l}1.20 \star \star \\
(0.36)\end{array}$ & $\begin{array}{c}0.16 \\
(0.17)\end{array}$ & $\begin{array}{l}-0.37 * \\
(0.17)\end{array}$ \\
\hline MGT & $\begin{array}{c}0.36 \\
(9.08)\end{array}$ & $\begin{array}{c}6.63 \\
(5.64)\end{array}$ & $\begin{array}{l}-7.28 \\
(5.52)\end{array}$ & $\begin{array}{c}22.32 \\
(11.93)\end{array}$ & $\begin{array}{r}-12.90 * \\
(5.61)\end{array}$ & $\begin{array}{l}-0.18 \\
(5.51)\end{array}$ \\
\hline OTHEX & $\begin{array}{r}-12.64 \\
(8.56)\end{array}$ & $\begin{array}{c}1.14 \\
(5.21)\end{array}$ & $\begin{array}{c}5.17 \\
(5.10)\end{array}$ & $\begin{array}{c}-5.94 \\
(11.16)\end{array}$ & $\begin{array}{c}1.46 \\
(5.05)\end{array}$ & $\begin{array}{c}0.36 \\
(4.96)\end{array}$ \\
\hline NONEX & $\begin{array}{l}-46.29 * * \\
(10.56)\end{array}$ & $\begin{array}{c}4.43 \\
(5.49)\end{array}$ & $\begin{array}{c}3.82 \\
(5.37)\end{array}$ & $\begin{array}{c}-2.34 \\
(10.97)\end{array}$ & $\begin{array}{l}-5.03 \\
(4.67)\end{array}$ & $\begin{array}{c}5.51 \\
(4.59)\end{array}$ \\
\hline$<35$ & $\begin{array}{l}12.54 \\
(6.97)\end{array}$ & $\begin{array}{c}4.15 \\
(3.94)\end{array}$ & $\begin{array}{l}-6.50 \\
(3.86)\end{array}$ & $\begin{array}{l}22.52 \star \star \\
(6.86)\end{array}$ & $\begin{array}{l}-0.74 \\
(3.12)\end{array}$ & $\begin{array}{l}-4.18 \\
(3.07)\end{array}$ \\
\hline$\geq 45$ & $\begin{array}{r}-11.67 \\
(7.65)\end{array}$ & $\begin{array}{c}2.54 \\
(4.36)\end{array}$ & $\begin{array}{c}3.88 \\
(4.27)\end{array}$ & $\begin{array}{l}-7.04 \\
(8.85)\end{array}$ & $\begin{array}{l}-1.31 \\
(3.66)\end{array}$ & $\begin{array}{c}1.72 \\
(3.59)\end{array}$ \\
\hline NONWHITE & $\begin{array}{l}-7.09 \\
(5.85)\end{array}$ & $\begin{array}{l}-1.11 \\
(3.33)\end{array}$ & $\begin{array}{c}3.87 \\
(3.26)\end{array}$ & $\begin{array}{l}-0.37 \\
(6.21)\end{array}$ & $\begin{array}{l}-5.58 * \\
(2.80)\end{array}$ & $\begin{array}{c}3.59 \\
(2.75)\end{array}$ \\
\hline $\begin{array}{l}\text { CONSTANT } \\
\text { Log of }\end{array}$ & $\begin{array}{c}-126.78 * * \\
(23.24)\end{array}$ & $\begin{array}{l}73.36 * * \\
(13.28)\end{array}$ & $\begin{array}{l}50.08 * * \\
(13.00)\end{array}$ & $\begin{array}{c}-156.47 * * \\
(25.61)\end{array}$ & $\begin{array}{c}49.11 * \\
(10.63)\end{array}$ & $\begin{array}{l}67.03 * * \\
(10.44)\end{array}$ \\
\hline likelihood & -1638 & -2889 & -2884 & -1273 & -3268 & -3256 \\
\hline
\end{tabular}

denotes $<.01 ; *$ denotes $\mathrm{p}<.05$. 
significantly positive, while YNGKID, OLDKID, NONWHITE, MARRIED, and MGT are all negative and significant. The equations run separately for men have fewer significant variables. In the ABC Work equation, EDUC and OWNINC are positively related and NONEX is significantly negative. In the Leisure equation, only MARRIED is significant, and it exhibits a large negative influence. Other Work again displays essentially the same significant variables as in Leisure, but with the opposite sign.

How should these results be interpreted? These equations do not show how a person allocates all of his or her time from scratch. Instead, the equations are applicable to the special case in which a person subject to a constraint on how much time may be spent working at a certain job for pay suddenly finds this constraint to be changed so that 16 hours a month must be reallocated away from paid work at $A B C$ into other areas.

It may be tempting to extrapolate from this story and argue that if a person were given yet another hour of free time, that this equation would predict how he would, on average, spend that hour. But these equations should be treated only as descriptive of the case for which they are estimated. If a person were given nine hours off instead of eight, his constraint would be different, and how he allocates time on the margin may be different from the percentage split found in these data.

These equations can, however, demonstrate how members of a population of workers, when faced with a worksharing program of this type, may vary in their time allocation behavior when various easily observed personal characteristics are taken into account. First, examine the $A B C$ Work equations. On average, the younger, better-educated, and higher-paid members of the workforce are more likely to spend a significant amount of time working at their primary job without pay. Perhaps this is because they look at the time as an investment in human capital and are the most 
willing to take on such an investment as they have the highest expectations of future returns. In contrast, those workers with lower income or a young child in their household prefer to invest their time in Other Work, presumably including childcare.

Upon observing the coefficients on the job-type dummies, it appears that exempt workers vary little in their time allocation. Nonexempt workers exhibit a negative relationship in two of the four $A B C$ Work equations and are never positively related to time spent working--this had been expected, given that their access to the firm was restricted on the days off. It is somewhat surprising that the MGT dummy did not enter with positive significance, as managers were hypothesized to feel obligated to work anyway. Perhaps this obligation is tied more to these persons' other characteristics, such as high salary and education levels, rather than to their job status.

Turning to the use of time as leisure, it is harder to see patterns, except that time spent in Leisure decreases for those persons with children and for married people. The nonleisure time is apparently spent in Other Work rather than in $\mathrm{ABC}$ Work.

\section{Results: Employee Reaction to STC}

In order to determine employee reaction to the STC program the sample respondents were asked to indicate how the practice of unpaid days off affected them personally. They responded by placing a mark on a nine-point line that was labeled "very negative" at one end, "very positive" at the other end, and "neutral" in the middle.11/ Separate questions were asked 
about the employee's reaction in August 1985 and December 1985. For most employees the responses were very similar for both months; therefore an average of the two was used in all subsequent analysis.

The distribution of responses, grouped into the nine categories, is shown in Figure 2. We see that positive reactions tend to outnumber the negative ones, and that there is a central tendency around "neutral." We also see a tendency for women to react more positively than men. In order to lessen the arbitrary nature of the scaling, all responses were classified into three categories: "positive," "negative," or "neutral," according to whether the mean score for the two months was above 5.5 , below 4.5 , or between or equal to those two values. Table 4 shows the distribution of responses in these three categories by sex and by other socioeconomic characteristics.

Overal1, approximately one-half of the employees reacted positively to the program, 29 percent were neutral, and 22 percent were negative. $12 /$ Women were more likely to be positive than men, but this sex difference was evident only for married persons. Because married women tended to react very positively to the program while married men were the least positive, there was no overall difference between married and not-married employees. The multivariate analysis described below takes account of this important sex-marital status interaction and possible other interactions with these variables.

The partial relation between employee reaction and socioeconomic characteristics was investigated by running ordered probit regressions with the dependent variable showing whether the response was positive, neutral, or negative. Operational1y, the underlying function for opinion about the short-time policy is specified as 


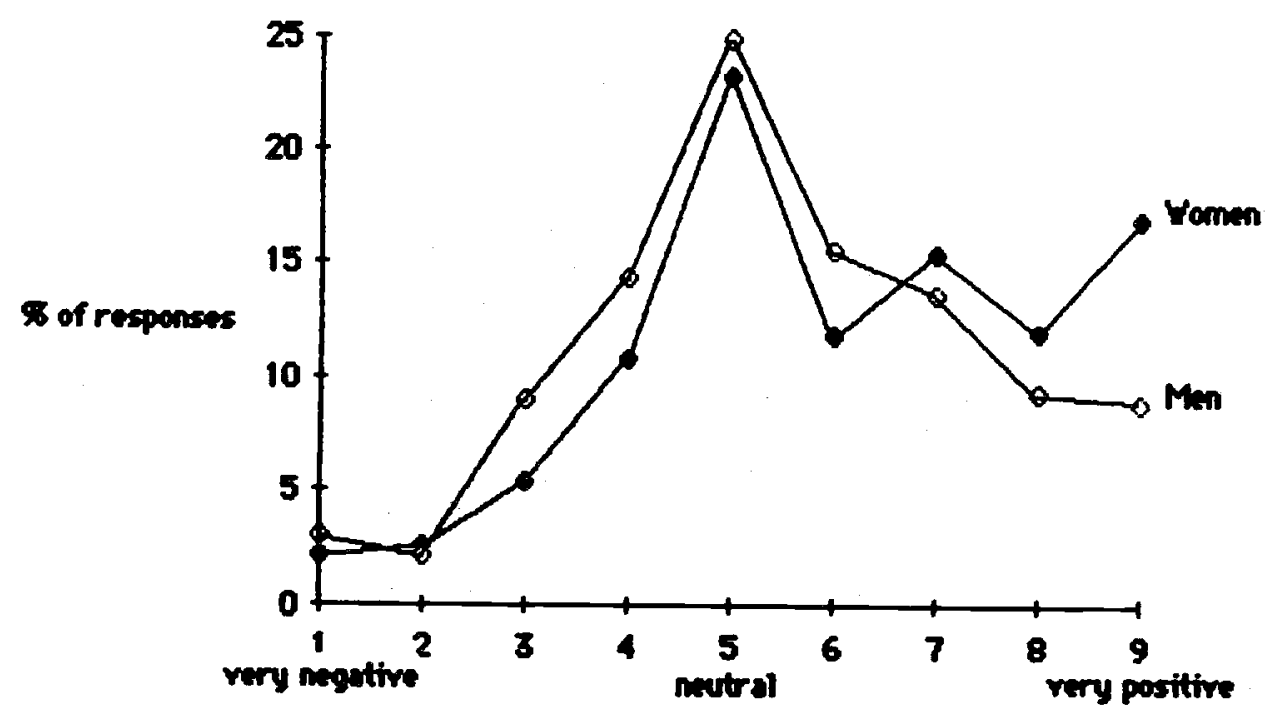

Figure 2. Distribution of responses by opinion of program, by sex. 
Table 4. Employee reaction to STC by socioeconomic characteristics.

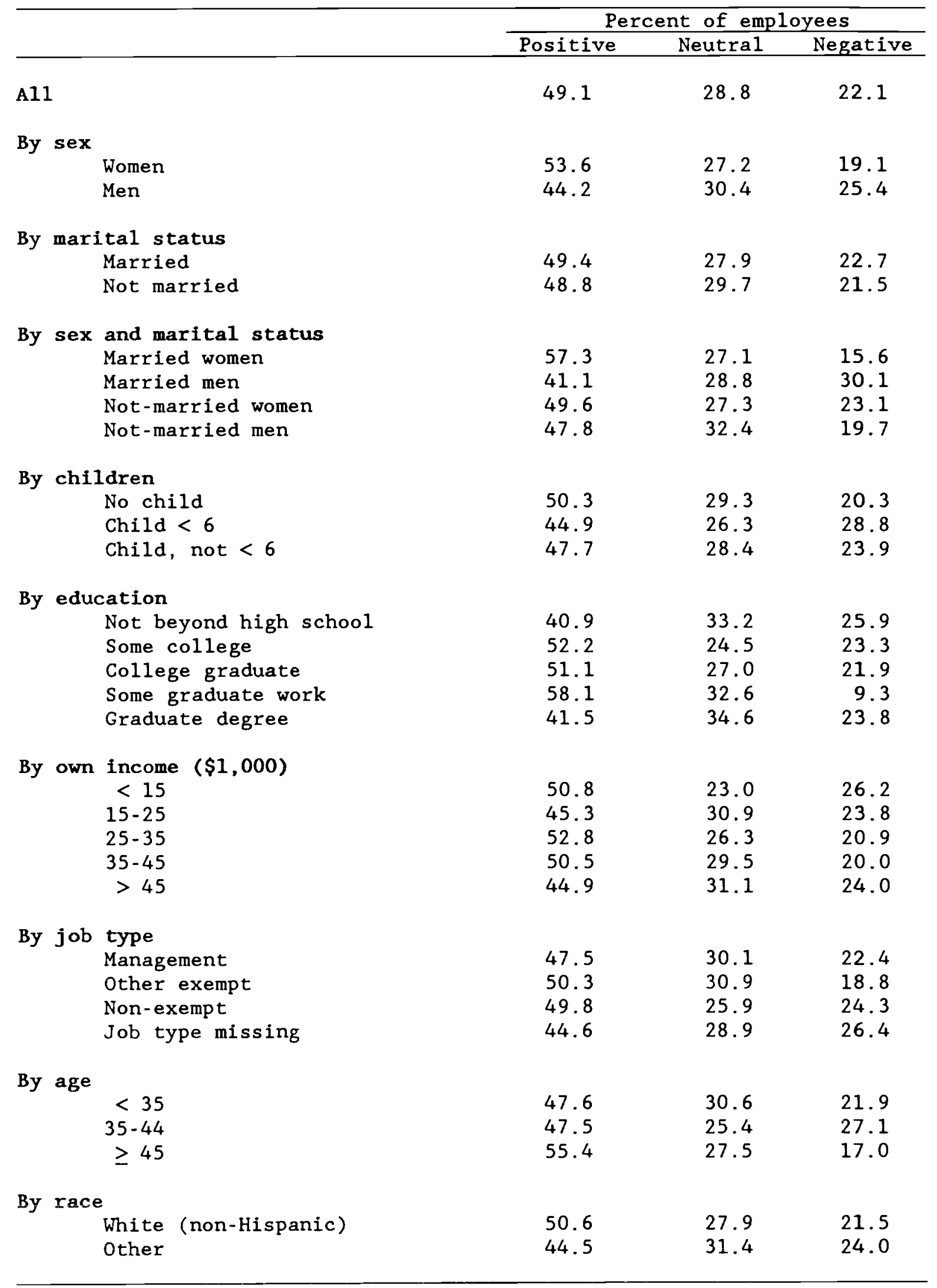




$$
Y_{i}^{*}-\beta^{\prime} X_{i}+u_{i}
$$

where $Y_{i}^{*}$ is the response of person $i, i=1,2, \ldots, n$

$x_{i}$ is a set of explanatory variables for $i$, and

$u_{i}$ is the residual.

Instead of observing $Y_{i}^{*}$, the following are observed:

$$
\hat{\delta}_{1}= \begin{cases}1 & \text { if person reports negative reaction } \\ 0 & \text { otherwise }\end{cases}
$$

$$
\delta_{2}= \begin{cases}1 & \text { if person reports a neutral reaction } \\ 0 \text { otherwise }\end{cases}
$$

$$
\delta_{3}= \begin{cases}1 & \text { if perzon reports a positive reaction } \\ 0 & \text { otherwise }\end{cases}
$$

$\mathrm{Y}$ is assumed to be distributed along the standard normal, and the following likelihood function is used to estimate the vector $\beta$ :

$$
L\left(\beta, \alpha \mid x_{i}, \delta_{1}, \delta_{2}, \delta_{3}\right)=
$$

$$
\prod_{i=1}^{n}\left\{\left[\Phi\left(-\beta x_{i}\right)\right]^{\delta}\left[\Phi\left(\alpha-\beta x_{i}\right)-\Phi\left(-\beta x_{i}\right)\right]^{\delta}\left[1-\Phi\left(\alpha-\beta x_{i}\right)\right]^{\delta}\right\}
$$

$\alpha$, the dividing point between positive and nonpositive opinion, is estimated as wel1, while the dividing point between negative and nonnegative opinion is normalized to zero. 
The sample was partitioned by marital status or by sex, and in each case two equations were estimated. The first included only the socioeconomic characteristics as right-hand-side variables; the second added two variables describing the employee's use of time.

The results, presented in Table 5, show that the difference between married women and married men is highly significant even after controlling for the other variables. One way to interpret these coefficients is to multiply them by the standard normal density function evaluated at a particular set of X's (e.g., the means of the independent variables). This yields the derivatives of the probabilities with respect to each independent variable, e.g.

$$
f_{k}=\frac{d \Phi\left(\beta x_{i}\right)}{d x_{i k}}=\phi\left(\beta x_{i}\right) \cdot \beta_{k}
$$

where $\beta_{k}$ is the $k$ th element of the parameter vector $\beta$. These are evaluated for significant $\beta_{k}$ 's, using the vector of the means of $X(\vec{X})$ for each sample group (married/not married, or men/women). They are evaluated in the regions of both the upper and lower dividing points:

$$
\begin{aligned}
& \hat{f}_{k}^{\text {upper }}=\phi\left(\hat{\alpha}-\hat{\beta}^{\prime} \bar{x}\right) \cdot \hat{\beta}_{k} \\
& \hat{f}_{k}^{\text {lower }}=\phi\left(-\hat{\beta}^{\prime} \bar{x}\right) \cdot \hat{\beta}_{k}
\end{aligned}
$$

With this method, the coefficient .408 in the first regression can be interpreted as indicating that women were 16 percentage points more 1 ikely to be positive than men (holding constant the other characteristics), and 
Table 5. Results of ordered probit regressions, probability of being positive, neutral, or negative about STC (standard errors in parentheses).

\begin{tabular}{|c|c|c|c|c|c|c|c|c|}
\hline & Married & $(\mathrm{N}=816)$ & Not married & $d \quad(N=707)$ & Men ( & $(N=729)$ & Women ( $\mathrm{N}$ & 794) \\
\hline WOMAN & $\begin{array}{l}.408 * * \\
(.11)\end{array}$ & $\begin{array}{l}.454 * * \\
(.11)\end{array}$ & $\begin{array}{l}.058 \\
(.09)\end{array}$ & $\begin{array}{l}.093 \\
(.10)\end{array}$ & 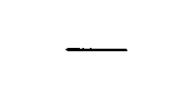 & - & $\longrightarrow$ & $\longrightarrow$ \\
\hline MARRI ED & - & - & - & 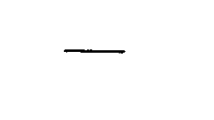 & $\begin{array}{l}-.298 \star \\
(.15)\end{array}$ & $\begin{array}{l}-.206 \\
(.16)\end{array}$ & $\begin{array}{l}-.083 \\
(.18)\end{array}$ & $\begin{array}{l}.032 \\
(.18)\end{array}$ \\
\hline YNGKID & $\begin{array}{l}.065 \\
(.11)\end{array}$ & $\begin{array}{l}.137 \\
(.11)\end{array}$ & $\begin{array}{l}-.370 \\
(.22)\end{array}$ & $\begin{array}{l}-.280 \\
(.23)\end{array}$ & $\begin{array}{l}.043 \\
(.14)\end{array}$ & $\begin{array}{l}.069 \\
(.14)\end{array}$ & $\begin{array}{l}-.150 \\
(.14)\end{array}$ & $\begin{array}{r}-.017 \\
(.14)\end{array}$ \\
\hline OLDKID & $\begin{array}{l}.035 \\
(.11)\end{array}$ & $\begin{array}{l}.108 \\
(.11)\end{array}$ & $\begin{array}{l}-.297 * \\
(.14)\end{array}$ & $\begin{array}{l}-.199 \\
(.15)\end{array}$ & $\begin{array}{l}.064 \\
(.14)\end{array}$ & $\begin{array}{l}.090 \\
(.14)\end{array}$ & $\begin{array}{r}-.169 \\
(.11)\end{array}$ & $\begin{array}{l}-.035 \\
(.12)\end{array}$ \\
\hline SPOUSINC & $\begin{array}{l}.006 \\
(.003)\end{array}$ & $\begin{array}{l}.005 \\
(.003)\end{array}$ & - & - & $(.000)$ & $\begin{array}{l}.000 \\
(.005)\end{array}$ & $\begin{array}{l}.010 \star \\
(.004)\end{array}$ & $\begin{array}{l}.008 \\
(.004)\end{array}$ \\
\hline EDUC & $\begin{array}{l}-.003 \\
(.02)\end{array}$ & $\begin{array}{l}.014 \\
(.02)\end{array}$ & $\begin{array}{l}.024 \\
(.03)\end{array}$ & $\begin{array}{l}.025 \\
(.03)\end{array}$ & $\begin{array}{l}.015 \\
(.03)\end{array}$ & $\begin{array}{l}.031 \\
(.03)\end{array}$ & $\begin{array}{l}.005 \\
(.02)\end{array}$ & $\begin{array}{l}.007 \\
(.02)\end{array}$ \\
\hline OWNINC & $\begin{array}{l}.000 \\
(.01)\end{array}$ & $\begin{array}{l}.002 \\
(.01)\end{array}$ & $\begin{array}{l}.003 \\
(.01)\end{array}$ & $\begin{array}{c}.004 \\
(.01)\end{array}$ & $\begin{array}{l}-.002 \\
(.01)\end{array}$ & $\begin{array}{l}.000 \\
(.01)\end{array}$ & $\begin{array}{l}.002 \\
(.01)\end{array}$ & $\begin{array}{l}-.003 \\
(.01)\end{array}$ \\
\hline MGT & $\begin{array}{r}-.015 \\
(.18)\end{array}$ & $\begin{array}{l}.005 \\
(.18)\end{array}$ & $\begin{array}{l}.221 \\
(.20)\end{array}$ & $\begin{array}{l}.320 \\
(.20)\end{array}$ & $\begin{array}{l}.256 \\
(.18)\end{array}$ & $\begin{array}{r}.257 \\
(.18)\end{array}$ & $\begin{array}{l}-.122 \\
(.20)\end{array}$ & $\begin{array}{l}.051 \\
(.21)\end{array}$ \\
\hline OTHEX & $\begin{array}{l}.098 \\
(.17)\end{array}$ & $\begin{array}{l}.054 \\
(.17)\end{array}$ & $\begin{array}{l}.307 \\
(.18)\end{array}$ & $\begin{array}{l}.318 \\
(.18)\end{array}$ & $\begin{array}{l}.269 \\
(.16)\end{array}$ & $\begin{array}{r}.256 \\
(.17)\end{array}$ & $\begin{array}{l}.098 \\
(.18)\end{array}$ & $\begin{array}{l}.082 \\
(.19)\end{array}$ \\
\hline NONEX & $\begin{array}{l}-.043 \\
(.16)\end{array}$ & $\begin{array}{l}-.028 \\
(.16)\end{array}$ & $\begin{array}{l}.271 \\
(.18)\end{array}$ & $\begin{array}{c}.234 \\
(.18)\end{array}$ & $\begin{array}{l}.121 \\
(.17)\end{array}$ & $\begin{array}{l}.079 \\
(.17)\end{array}$ & $\begin{array}{l}.010 \\
(.17)\end{array}$ & $\begin{array}{r}.050 \\
(.17)\end{array}$ \\
\hline$<35$ & $\begin{array}{l}-.161 \\
(.11)\end{array}$ & $\begin{array}{l}-.123 \\
(.11)\end{array}$ & $\begin{array}{l}.278 * \\
(.13)\end{array}$ & $\begin{array}{l}.259 * \\
(.13)\end{array}$ & $\begin{array}{l}-.091 \\
(.12)\end{array}$ & $\begin{array}{l}-.097 \\
(.12)\end{array}$ & $\begin{array}{l}.114 \\
(.11)\end{array}$ & $\begin{array}{l}.152 \\
(.11)\end{array}$ \\
\hline$\geq 45$ & $\begin{array}{l}.229 \\
(.12)\end{array}$ & $\begin{array}{l}.231 \\
(.12)\end{array}$ & $\begin{array}{l}.478 \star \star \\
(.16)\end{array}$ & $\begin{array}{l}.458 * * \\
(.16)\end{array}$ & $\begin{array}{l}.229 \\
(.14)\end{array}$ & $\begin{array}{l}.204 \\
(.14)\end{array}$ & $\begin{array}{l}.300 * \\
(.13)\end{array}$ & $\begin{array}{l}.322 \star \\
(.14)\end{array}$ \\
\hline NONWHITE & $\begin{array}{l}-.055 \\
(.10)\end{array}$ & $\begin{array}{l}-.070 \\
(.10)\end{array}$ & $\begin{array}{l}-.158 \\
(.11)\end{array}$ & $\begin{array}{l}-.127 \\
(.11)\end{array}$ & $\begin{array}{l}-.124 \\
(.10)\end{array}$ & $\begin{array}{l}-.135 \\
(.10)\end{array}$ & $\begin{array}{l}-.053 \\
(.10)\end{array}$ & $\begin{array}{l}-.007 \\
(.10)\end{array}$ \\
\hline ABCWORK & $\underline{-}$ & $\begin{array}{l}-.014 * \star \\
(.002)\end{array}$ & - & $\begin{array}{l}-.011 * * \\
(.002)\end{array}$ & $\underline{-}$ & $\begin{array}{l}-.011 * * \\
(.002)\end{array}$ & - & $\begin{array}{l}-.015 * \star \\
(.002)\end{array}$ \\
\hline OTHWORK & $\ldots$ & $\begin{array}{l}-.010 * * \\
(.002)\end{array}$ & 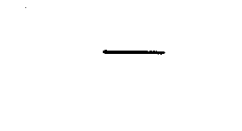 & $\begin{array}{l}-.007 * * \\
(.002)\end{array}$ & $\overline{ }$ & $\begin{array}{l}-.008 * * \\
(.002)\end{array}$ & - & $\begin{array}{l}-.011 * x^{2} \\
(.002)\end{array}$ \\
\hline CONSTANT & $\begin{array}{l}.438 \\
(.36)\end{array}$ & $\begin{array}{l}.778 * \\
(.38)\end{array}$ & $\begin{array}{l}-.132 \\
(.44)\end{array}$ & $\begin{array}{l}.217 \\
(.45)\end{array}$ & $\begin{array}{c}.482 \\
(.41)\end{array}$ & $\begin{array}{r}.600 \\
(.42)\end{array}$ & $\begin{array}{r}.533 \\
(.38)\end{array}$ & $\begin{array}{l}1.02 * * \\
(.40)\end{array}$ \\
\hline $\begin{array}{l}\alpha \\
\log \text { of }\end{array}$ & .796 & .837 & .842 & .866 & .825 & .853 & .802 & .844 \\
\hline likelihood & -825 & -796 & -722 & -706 & -770 & -752 & -783 & -754 \\
\hline
\end{tabular}

denotes $\mathrm{p}<.01 ; *$ denotes $\mathrm{p}<.05$ 
that they were 12 percentage points less likely to be negative. The sexmarital status interaction shows up as well in the regression for men where the coefficient -.298 translates into married men having 12 percentage points less probability of being positive and 8 percentage points more likely to be negative than not-married men. In the regressions limited to women a statistically significant relationship is found for spouse's income. The higher the spouse's income the more likely a woman is to react positively. The coefficient for marital status in the women's regression is not statistically significant, suggesting that fo: women the amount of money the husband makes is more important than marital status per se. $\underline{13 /}$

The presence of children produces a more positive response for married persons and for men, and a more negative response for not-married persons and women, but only one coefficient is statistically significant. Age is significant in several specifications. In general, those employees who were 45 and over were much more positive about the program than those between 35 and 45 . In the case of not-married employees, for instance, the coefficient of .478 (when evaluated at the means of the variables) implies that employees 45 and over were 19 percentage points more likely to be positive than the 35-44 age group, and 13 percentage points less likely to be negative. Among the not-married, younger workers (under 35) tended to be more positive about the program than those $35-44$, but this was not true for married employees. The coefficients for education, own income, job type, and race are not statistically significant.

One of the strongest and most consistent results is the relation between time use and reaction to the program. The more time an employee spent in $A B C$ Work or Other Work, the more likely was the reaction to be 
negative, and this was true regardless of marital status or sex. The coefficient of -.010 for married employees, for instance, implies that, ceteris paribus, an employee who spent all his or her time in Other Work was 40 percentage points less likely to be positive about the program and 30 percentage points more likely to be negative than an employee whose time was devoted entirely to leisure. Employees who spent their time at $A B C$ Work were least likely to be positive about the program; the difference between the $\mathrm{ABC}$ Work and other Work coefficients typically come close to but do not quite reach the .05 level of significance.

Respondents were invited to supplement their replies to the survey with written comments, and one-fourth of the employees did so. About 57 percent of the comments amplified reactions to the program; the other comments clarified answers regarding socioeconomic characteristices, gave opinions about the study, or described feelings (mostly negative) about the employment and wage policies instituted by $A B C$ after the end of the STC program.

Of the detailed comments that concerned reaction to the program, 65 percent were positive, 10 percent negative, and 25 percent were mixed (included both positive and negative reactions). Thus the employees who felt strongly enough about the program to provide written comments tended to be more positive than the sample as a whole. The difference between women and men that was noted in the survey responses was also present in the comments: the number of positive/negative comments was $64 / 7$ for married women, $36 / 11$ for married men, and $53 / 6$ and $33 / 5$ for not-married women and not-married men, respectively.

A detailed reading of positive comments revealed two primary themes. Some employees liked the STC program because they preferred it to a program of layoffs. $14 /$ other employees reacted positively because they 
actually preferred the shorter work time, albeit with lower pay. $15 /$ The negative comments stressed the financial hardship of adjusting to 10 percent less income and the difficulty of making the best possible use of the days off. Some of the negative comments indicated that the workload did not decrease at their job; thus they felt they had to work harder on the days that they were employed.

\section{Discussion}

This survey of California workers who experienced 10 percent reductions in hours and pay for six months in 1985 shows that use of the time off and opinion of the program varied systematically with socioeconomic characteristics. Ceteris paribus, the propensity to come in to work anyway rose with education and income, and fell with age. The presence of children (especially under age 6) resulted in an appreciable increase in the percentage of time devoted to Other Work (mostly home production), especially for women. Employee reaction to the program was most positive among married women and least positive among married men. Age was also related to reaction, with older workers (45+) feeling most positive and those ages 35-44 feeling least positive. One of the strongest and most consistent results was a positive association between percentage of time spent in Leisure and reaction to the program.

The strong relationship between time use and opinion of the program suggests that for many workers the time off was not truly "free time." The use that they made of it was constrained in ways that affected their opinion of the program. For instance, some employees apparently felt obliged to come in to work anyway on an unpaid basis. Similarly, some 
employees must have felt constrained to do other work (such as household chores), and the more they did the less likely they were to think positively of the program.

The results indicate that differences in sex roles are important, even among a sample of persons all of whom hold regular full-time jobs. The effect of sex on opinion of the program varies with marital status, and the effect of children on time use varies with sex. An interaction between age and sex also appears in the propensity to come in to work on the day off. Women under age 35 were much more likely to do so than those 35 and over.

The generally positive reaction to the program suggests that other firms might give serious consideration to compulsory short-time work as an alternative to layoffs. From a public policy perspective there seems to be little reason to provide unemployment insurance compensation for layoffs, but not for compulsory short time. To be sure, these results are based on employees in only one company, and one needs to be careful about generalizing to the employed population as a whole. Moreover, the basis for the generally positive reaction to the program is ambiguous. Some employees were positive because they preferred it to layoff, whereas others actually preferred STC to a full-time, full-pay schedule. Whether they would have done so in the absence of the unemployment insurance subsidy is not known.

These results should be interpreted with caution and qualifications, but they do have the virtue of arising from a real situation, not a hypothetical question, and they do cover a fairly large sample of workers. The implications for gender roles, age, and presence of children on hours of work and use of unpaid time seem important and worthy of further investigation. 
FOOTNOTES

1. The hypothetical question indicated that workers on STC would receive one-half of their pre-tax hourly wage for each hour lost from their regular workweek.

2. Eight industries with zero worksharing were eliminated from the analysis to avoid clustering. This reason is not persuasive.

3. An exception was made for two small groups who were working on projects that were deemed vital to the future profitability of the company. One of these groups, which was not located in a division that was surveyed, worked on its usual schedule. The other group, which was located in a surveyed division, was put on a 110 percent time for 100 percent pay program, in which they were expected to come in on alternate Saturdays for a full day.

4. Some of these were from people who were not covered by the program, either because they were on leave in one or both of the months referred to on the questionnaire, or because they were not working at the firm at that time. Others were from people who were incorrectly included in our sample who were actually on the schedule of working extra weekend hours without pay.

5. Examination revealed that there were not significant differences by division with respect to time use and opinion, so the divisions were pooled for the subsequent analysis.

6. In the sample of 1,523 persons used in the following statistical analysis, the mean amount of time spent in volunteer work was 1.0 percent; in paid work, 2.4 percent. Even among those people who reported spending a positive amount of time in one or the other category the amount of time 
was not substantial--83 persons did volunteer work, for an average of 17.8 percent of their time; 105 persons spent an average of 35.4 percent of their time in paid work.

7. Some problems were encountered in the course of coding the answers to this question. Occasionally the time use figures did not add up to 100 percent; in these cases the figures were summed and renormalized by their total. Several people were not sure where to classify their holiday shopping--they would either place it in the "other" category or indicate in a comment by their placement of it in either the leisure or chores category that they were making a somewhat arbitrary decision as to how to categorize this activity. Such time use was split 50-50 between the Leisure and Other Work categories.

8. As one manager commented, "Given that my job requires $50+$ hours per week (60-70 hours per week during the program), telling me I should take a day off was ridiculous."

9. To check for specification error, the model was rerun under the two alternative specifications of decision order. There are no cases in which a significant sign reversal occurs, but some magnitudes become up to twice as 1 arge and some parameters become significant which are not significant in the reported equations.

10. Raising the top constraint on either Other Work or Leisure from (100 - ABC Work) to 100 does not significantly change the parameter estimates from those reported here.

11. See the appendix.

12. The 261 replies that were excluded from the analysis because of missing data showed a slightly less favorable reaction: 43 percent positive, 30 percent neutral, and 27 percent negative. 
13. If SPOUSINC is deleted from the equation, the coefficient for MARRIED is positive and significant at $p<.01$.

14. E.g., "My personal feelings about the unpaid time off was quite positive due to my appreciation for $\mathrm{ABC}^{\prime}$ s philosophy"; "I very much appreciated having a job and now am very willing to share losses as well as profits."

15. E.g., "The time off meant more to me than the pay for one day"; "Thoroughly enjoyed the time off--would love to continue it. Allowed me to spend time with my child." 
Best, Fred. 1985. "Short-Time Compensation in North America: Trends and Prospects," Personnel (January), pp. 34-41.

Best, Fred. 1981. Work Sharing, Kalamazoo, Michigan, W. E. Upjohn Institute for Employment Research, pp. 108-109.

Best, Fred, and James Mattesich. 1980. "Short-Time Compensation Systems in California and Europe," Monthly Labor Review (July), pp. 13-22.

Blyton, Paul. 1985. "Short-Time Working," Changes in Working Time: An International Review, pp. 89-100.

Business Week. 1986. "Shorter Workweeks: An Alternative to Layoffs" (April 14), pp. 77-78.

McCoy, Ramelle, and Martin J. Morand. 1984. "Short-Time Compensation: The Implications for Management," in Ramelle MaCoy and Martin J. Morand, eds., Short-Time Compensation: A Formula for Work Sharing, New York: Pergamon Press. (pp. 14-35)

Meisel, Harry. 1984. "The Pioneers: STC in the Federal Republic of Germany," in Ramelle MaCoy and Martin J. Morand, eds., Short-Time Compensation: A Formula for Work Sharing, New York: Pergamon Press, (pp. 53-60)

Meltz, Noah M., Frank Reid, and Gerald S. Swartz, Sharing the Work: An Analysis of the Issues in Worksharing and Jobsharing, Toronto, University of Toronto Press, 1981.

Nemirow, Martin. 1984. "Work-Sharing Approaches: Past and Present," Monthly Labor Review (September), pp. 34-39.

Reid, Frank, and Noah M. Meltz. 1984. "Canada's STC: A Comparison with the California Version," In Ramelle MaCoy and Martin J. Morand, eds., 
Short Time Compensation, A Formula for Work Sharing, New York,

Pergamon Press, p. 108.

State of California. 1982. California Shared Work Unemployment Insurance

Evaluation, Employment Development Department, Health and Welfare Agency, Sacramento, CA (March).

Wales, T. J., and A. D. Woodland. 1983. "Estimation of Consumer Demand Systems with Binding Non-Negativity Constraints," Journal of Econometrics (April), pp. 263-285. 


\section{APPENDIX}

Hello: We are two Stanford researchers conducting a study of people's attitudes towards work schedules. W1th ABC's help, we are conducting this voluntary survey in several divisions. If you could spend a few minutes f1lling out this short anonymous questlonnalre, we'd appreclate your help. Feel free to contact us at (415) 326-7639 1f you have any questions to us in the attached postage-pald envelope. Naturally, we will share the overall results of our study with ABC though not the Individual data. Many thanks for
your help.

Sincerely,

Victor R. Fuchs, Professor of Economics

Joyce Jacobsen, graduate student

1. ABC began a series of unpald days off last summer. We are interested in hoy you spent this time, espeacially in any changes ever this period. Please estimate the percent of this time that you spent in each category:
a) In August. 1985
b) In Decenber, 1985

1) Did hobbles, sports, travel, or rested

2) Did housework, chores, errands, or chlld care

3) Performed volunteer work

4) Came to work at $\mathrm{ABC}$ anyway

5) Performed other work for pay

6) Other (please specify):

TOTAL:
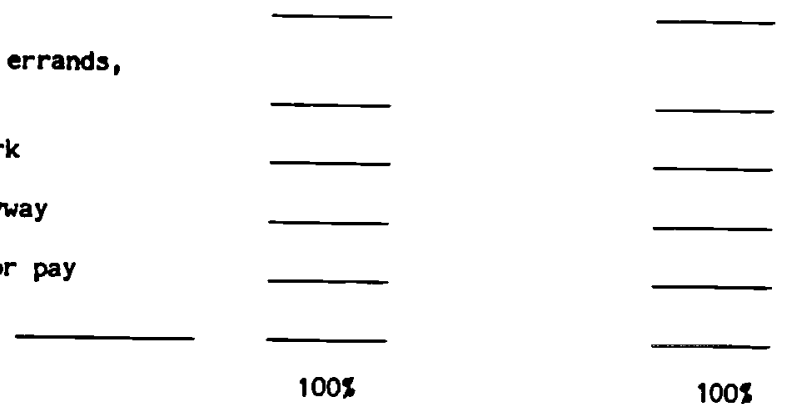

Other:

2. Hou did ABC's practice of unpaid days off affect you personally? (Please place a mark on the line at the point which corresponds to the effect on you, as best you can remenber.)

a) In August, 1985:

very negat1ve neutral

very positive

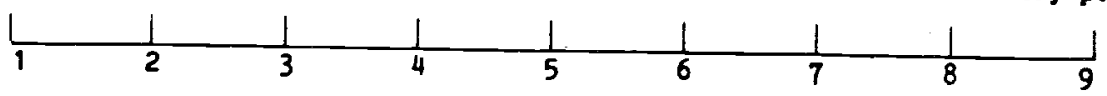

very negative

very positive

b) In December 1985:

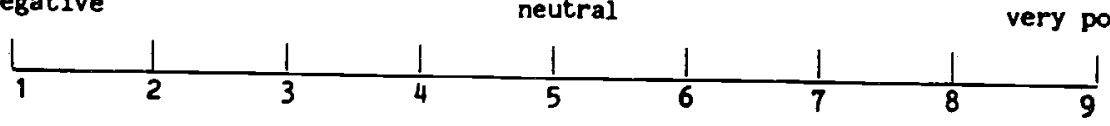

3. What is your iob at ABC?

\section{BLEASE CIRCLE ANSWERS FOR THE RDATMTNG OUESTIONS.}

4. What is your sex?

Male / Female

5. What is your age?

under $25 / 25-34 / 35-44 / 45-54 / 55-64 /$ over 64

6. What is your race? White (Non-H1spanic) / Black (Non-H1span1c) / H1span1c / Aslan or Pac1fic Islander / Other

7. What is the rance of your anmual salary?

under $\$ 15,000 / \$ 15,000-25,000 / \$ 25,001-\$ 35,000 / \$ 35,001-\$ 45,000 / \$ 45,001-\$ 60,000 /$ over $\$ 60,000$

8. What is your hishest level of schooling?

Less than h1gh school grad / HIgh school grad / Some college / College grad / Sone grad work / Graduate degree

9. a) How many children under age 6 live in vour household? None / $1 / 2 / 3 / 4$ or wore

b) How mank chlldren between ages 6 and 18 ?

None / $1 / 2 / 3 / 4$ or more

10. a) Does your spouse work for nay?

Don't have one / No / Yes-part-time / Yes-rull-time

b) If yes. what is the rance of your spouse's annual salary?

under $\$ 15,000 / \$ 15,000-25,000 / \$ 25,001-35,000 / \$ 35,001-45,000 / 45,001-60,000 /$ over $\$ 60,000$

Again, comments on the beck of this sheet are welcome. Thank you for your participation. 